\title{
Health Consequences of Child Marriage in Rural and Urban Communities: Comparative Study
}

\section{Nabila El Sayed Sabola', Naglaa Abdel mawgoud Ahmed', Hemat Mostafa Amer ${ }^{3}$, Walaa Mohamed Abdo ${ }^{4}$}

1Prof. of Family and Community Health Nursing, Faculty of Nursing, Menoufia University, Egypt.

${ }^{2}$ Assis.Prof. of Family and Community Health Nursing, Faculty of Nursing, Menoufia University, Egypt.

${ }^{3}$ Lecture of Family and Community Health Nursing, Faculty of Nursing, Menoufia University, Egypt.

${ }^{4}$ B.Sc Nursing in Al- Shohadaa hospital, Menoufia Governorate, Egypt.

\section{Abstract:}

Background: Child marriage threatens children's well-being and constitutes multiple violations of their rights. The aim of this study is to assess health consequences of child marriage in rural and urban communities. Design: A descriptive comparative design. Setting: Study was conducted atone maternal \& child health center and one health unit for both urban and rural communities respectively, Menoufia governorate, Egypt. Subjects: A purposive sample of 370 women attended at mentioned places. Instruments: Structured interviewing questionnaire included: socio-demographic data, women perception and attitudes of child marriage, and perception bio-psycho-social health consequences of child marriage. Results: the prevalence of child marriage was $18.5 \%$, the majority of the studied women have poor perception of the child marriage, there was no statistical significant difference regarding the perception of reasons for child marriage, which includes: tradition, education failure, insufficient income or poverty, \& the marriage of a cousin or a relative, by $35.8 \%$ in rural area and $40.5 \%$ in urban area.. Finally, there was high statistical significant difference regarding bio psychosocial consequences of child marriage between urban and rural communities. Conclusion: Child marriage prevalence in rural and urban areas was significant problem and has negative adverse bio psychosocial consequences for both urban and rural communities. Recommendation: raising awareness about negative outcomes of child marriage by intensifying the health education activities and enhancing culture \&community perception.

Keywords: Child marriage, Health consequences, Woman's health. 


\section{Introduction}

Child Marriage is defined as a marriage of a girl or a boy before the age of 18 years and refers to both formal marriages and informal unions in which children under the age of 18. Child marriage affects both girls and boys, but it affects girls disproportionately ${ }^{(\mathbf{1})}$. The Universal Declaration of Human Rights recognizes the right to "free and full" consent to a marriage, acknowledging that consent cannot be "free and full" when one of the individuals involved is not sufficiently mature to make an informed decision about a life partner ${ }^{(2)}$.

The prevalence of child marriage is found to be higher in the rural areas in the developing world. According to UNFPA, 44 percent of the women between the ages of 20-24 in rural areas are entering marriage before they reach adulthood, in contrast to the urban areas, where only 22 percent of women in the same age are being exposed to child marriage ${ }^{(3)}$.

Perception and attitudes of child marriage which are the broad domain of social norms, ethics, morals, values, rights, culture, tradition, spirituality and religion, and feelings about self and others are rooted in many issues ${ }^{(\mathbf{1})}$.Causes of child marriage include; poverty, dowry, cultural traditions, laws that allow child marriages, religious and social pressures, regional customs, fear of remaining unmarried, illiteracy, natural disasters and war. All of these increase the chance of sexual violence against girls, protecting the family honor and family ties in which marriage is a means of consolidating powerful relations between families ${ }^{(4)}$.

Consequences of child marriage are drawn in isolated and limited freedom, married girls often feel disempowered. They are deprived of their fundamental rights to health, education and safety. Child girls are neither physically nor emotionally ready to become wives and mothers. Young married girls are more likely to be illiterate and of low social status. They tend to have no access to financial resources and restricted mobility; they are limited in their ability to obtain information on reproductive health, contraception and sexually transmitted infections, complications in pregnancy and childbirth and suffering domestic violence $^{(5)}$.

Child marriage is a form of violence which disproportionally affects girls. One 
in three women and girls experience violence in their lifetime, while parents often marry their daughters as a way of protecting them from harm. Child marriage exposes girls to intimate partner violence, including sexual, physical, psychological and emotional violence ${ }^{(6)}$.

Community health nurse has a big role in identifying immense need to undertake research on deeper understanding of the determinants of child marriage from girls' own perspectives, while giving the importance of child marriage and its impacts on health of adolescents and the role of culture as the main determinants of age at marriage. It will contribute to designing and developing culturally responsive interventions and improving the health programs for this girl ${ }^{(7)}$.

Working with communities to change their attitudes toward girls through ensuring that girls are more highly valued, supporting girls to stay in school and continue their education and providing safe spaces and support networks for girls at risk for child marriage .Nursing role is also Engaging with religious leaders to encourage them to take a greater role in condemning child marriage and changing community attitudes and patriarchal attitudes whilst also supporting young people and youth groups to become agents of change. Using media channels to raise awareness and highlight the negative consequences of child marriage ${ }^{(8)}$.

\section{Significance of the study}

According to the Egyptian Census of population at 2017, child marriage remains an issue. In Egypt, nearly 1 in every 20 girl between the age of 15 to 17 years off married and 1 in every $10(11 \%)$ adolescent girl's years are either currently married or were married before with large differentials between the rural and urban residence. In Egypt $17 \%$ of girls are married before the age of 18 and $2 \%$ are married before the age of 15 . According to UNICEF, Egypt has the $13^{\text {th }}$ highest absolute number of child married girls in the world ${ }^{(9)}$.

Purpose of the study: Assess health consequences of child marriage in rural $\&$ urban areas.

Research questions: The following research questions are formulated to achieve the purpose of the study:-

- What is the prevalence of child marriage in rural and urban communities?

- What are the women's perception and attitudes for child marriage in rural and urban communities? 
- What are the health consequences of child marriage in rural and urban communities?

\section{Subjects and Methods}

Design: A descriptive comparative design was used to achieve this study.

Study Setting: This study was conducted in maternal \& child health center $(\mathrm{MCH}), \mathrm{Al}-\mathrm{Shohadaa}$ district as an urban community and health unit, Met Abo ElKom village as a rural community, Tala district, Menoufia governorate, Egypt .A multistage random selection of the setting according to the following steps as: Two districts from all districts of Menoufia governorate (nine districts) were selected using simple random sample. These districts were Al Shohadaa and Tala as mentioned.

Study Subject: Calculation of prevalence of the child marriage among studied women at the beginning single questions for 2000 women attended to two previous mentioned settings about current age and age at marriage to determine the frequency of child marriage among women, The sample of 370 women married early derived from total number of 2000, the study conducted for six months.. Subjects were recruited female from Al Shohadaa and Tala as $50 \%$ for rural and $50 \%$ for urban communities that selected from the previously mentioned settings according to the following inclusion criteria:

- Women married prior to 18 years and have at least one child birth.

- Women married for at least 2 years to ensure that they experienced the marital life.

Sample size calculation: calculation for the current descriptive study rendered 370 women who married early based on 2000 . Calculation of the sample size to assess the health consequences of child marriage in rural and urban areas.

\section{The following sample size equation was} used:

$n=\frac{z_{(1-\alpha / 2)}^{2} p(1-p)}{d^{2}}$

\section{Where:}

$\boldsymbol{n}=$ Sample size

$\mathbf{Z}_{(\mathbf{1 - \alpha} / \mathbf{2})}^{\mathbf{2}}=$ reliability coefficient

$\boldsymbol{P}=$ Percent of outcome in the population

$$
d=\text { precision }=\mathbf{5 \%}
$$

\section{Our assumptions were:}

- Reliability coefficient $=1.96$

- Percent of child marriage in the population $(p)=17 \%$ (prevalence rate of child marriage among girls 
in the Middle East according to

(UNICEF, 2015) ${ }^{(10)}$.

- Precision $=5 \%$

- Ratio of rural : urban is $1: 1$

So the calculated sample size for this descriptive study rendered 370 females, who experienced child marriage, and based on the ratio of rural/urban is 1: 1 (i.e. 185 in each group). Participant females from each of rural or urban area were selected randomly by the researcher.

\section{Study Instrument}

Structured interviewing questionnaire (p1) :

Developed by the researchers after reviewing the related national and international literature, discussion with experts to collect data about the subjects and was written in simple Arabic language to suit level of understanding of the subjects. It contained the following parts:

-Socio-demographic characteristics included name, age, sex, marital status occupation, address, level of education and monthly income.

-Women perception and attitudes toward child marriage such as family tradition, educational status, family income and endogamy.
-Women perception about bio-psychosocial health consequences of child marriage.

\section{Scoring system}

The questionnaire contained, items related to the participants' demographic criteria as current age, age of marriage, residence, level of education as well as women' knowledge assessment items; two responses as (1) for "No" answer, and (2) for "Yes" answer. The questionnaire was evaluated giving total score of $4-8$ degree categorized arbitrary into "good knowledge" when the woman achieved more than $>50 \%$ of the total score, and "poor knowledge" was considered when the mother achieved less than or equal to $\leq$ $50 \%$ of the total score. Concerning attitude of women, the researcher studied it in a list of 11 items, each item was two responses as (1) for "not agree" (2) for "agree"; The questionnaire was evaluated giving a score of $11-22$ categorized arbitrary into "positive attitude" when the woman achieved more than $>50 \%$ of the total score and "negative attitude" was considered when the mother achieved less than or equal to $\leq 50 \%$ of the total score.

\section{Validity and Reliability}

Validity of the questionnaire was assessed using content validity by three experts in 
the fields of family and community health nursing, maternal \& newborn health nursing and community medicine. The relevancy, clarity, fluency and simplicity of each component in the questionnaire were examined and needed modifications were applied.

Reliability of the tool was tested by (testretest) manner for the measuring of the internal consistency by administration of the same tool to the same participants on two or more occasions, with two weeks apart between them, and then results were compared by Cronbach score of reliability test which was $\mathrm{R}=0.81 \%$.

Cronbach score of reliability test was done also to the second part of the tool (perception of causes of child marriage), third part (women attitude toward child marriage) and the fourth part (Perception of adverse bio-psycho-social health consequences of child marriage) of the tool with Cronbach alpha of $0.83,0.80$ and 0.78 respectively.

\section{Pilot Study}

A pilot study was conducted on $10 \%$ women to assess the feasibility of the study as well as clarity and objectivity of the tools. The needed modifications were incorporated to add or omit questions if needed, the time required for tool fulfillment were calculated. Pilot study sample were excluded from the total study sample size.

\section{Administrative \&ethical consideration}

An official letter to conduct the study obtained from the administrator of the faculty of nursing then approval of the research was obtained from the Ethics Committee of Scientific Research in the faculty of Nursing, Menoufia University before starting of the study\& performed to the administrator of each setting to permit collecting of research data. Ethical considerations included: Apply the subjects' rights to freely choice to participate in the study, the rights of privacy and safety for the subjects were secured and they were allowed to withdraw from the study whenever they wanted.

\section{Field work}

-The study conducted firstly by an official permission that was obtained from the directors of both maternal and child health districts.

- Calculation of prevalence of the child marriage among studied women assessed by single questions about current age and age at marriage to determine the frequency of child marriage among women after calculation of the sample size, the study 
conducted for six months.

-The researcher introduced herself to the women, the aim of the study was explained .Selecting for counseling room in both rural and urban areas for the subjects interview in order to assure privacy and freely reporting information, the room has two seats for the subject and researcher in order to keep confidentiality.

-Oral consent was obtained from participants after explanation of the purpose of the study to gain their cooperation with promise of close confidentiality of data.

- A structured interview was conducted individually for the study subjects the tool was questionnaire given for each woman under observation of the researcher. While illiterate women the researcher helped them to fill it, questionnaire took about 20-30minute to be answered.

-The interview was carried out for two days( Saturday\& Tuesday per week from the $10: 00 \mathrm{AM}$ to $1: 00 \mathrm{PM}$ according to available number of females for six months at February - July (2019).

\section{Statistical Analysis}

Data was coded and transformed into specially designed form to be suitable for computer entry process. Data was entered and analyzed by using SPSS (Statistical Package for Social Science) statistical package version 22. Graphics were done using Excel program.

Quantitative data as age were presented by mean $(\mathrm{X})$ and standard deviation (SD). Qualitative data were presented in the form of frequency distribution tables, number and percent. It was analyzed by chi-square $\left(\chi^{2}\right)$ test. However, if an expected value of any cell in the table was less than 5, Fisher Exact test was used( if the table was 4 cells), or Likelihood Ratio (LR) test (if the table was more than 4 cells). Level of significance was set as $\mathrm{P}$ value $<0.05$ for all significant tests.

\section{Results}

Fig (1): shows that prevalence of child marriage among 2000 of married woman is $18.5 \%$, the studied women who live in urban areas, showed slightly higher prevalence in age between 14-17 years $(97.8 \%)$, with mean of $16.4 \pm 1.7$ years, compared to $95.7 \%$ among women who live in rural areas with mean age of $15.2 \pm$ 2.1 years respectively however, the difference was not significant statistically $(\mathrm{p}=0.24 \& \mathrm{p}=0.71)$.

Table (1): shows that, $55.1 \%$ of the studied females, who live in rural areas, their age was between 16 to 26 years with mean of $23.1 \pm 2.7$ years, while $44.9 \%$ of the studied females, who live in urban areas, their age was between 16 to 26 years with mean of $24.4 \pm 3.1$ years, the difference was not 
significant statistically $(\mathrm{P}=0.09)$. The studied females who live in urban areas, showed a slightly higher mean age of marriage $(16.4 \pm 1.7)$ years , compared to $15.0 \pm 2.1$ years among women live in rural area, however, the difference was not significant statistically $(\mathrm{P}=0.71)$. The same trend was observed in occupation and marital status $(\mathrm{P}=0.42$, and $\mathrm{P}=0.07$ respectively. Concerning level of education, a higher significant difference of moderate education was observed among females living in urban areas compared to those who live in a rural areas $(\mathrm{P}=0.001)$.

Table (2) demonstrates that, there were no statistical significant difference among rural and urban studied women regarding to their perception about child marriage except at the point of equality between girls and boys in society .Regardingto the reasons for child marriage, the highest percent was "all of above" (which includes :tradition, education failure, Insufficient income or poverty, \& the marriage of a cousin or a relative), $35.8 \%$ in rural area and $40.5 \%$ in urban area. All family members were encouraged these women to child marriage, with a higher percent in rural area $(83.2 \%)$ than in urban area (81\%), however, this difference was not statistical significant $(\mathrm{P}=0.55)$.

Fig (2): shows that there was statistical significant difference $\mathrm{p}=(0.04)$ in a total attitude toward child marriage score in rural
$\&$ urban areas in which rural positive attitude $(31.9 \%)$ more than urban $(22.7 \%)$, while the negative attitude of rural women $(68.1 \%)$ less than the urban females attitude $(77.3 \%)$.

Table (3): demonstrates that child marriage effects on their physical health considering the occasional bleeding $p=$ (0.000), and vaginal secretions due to vaginitis $(p=0.03)$ are major health effects with no statistical difference between $90.3 \%$ of rural and urban women.

Table (4): demonstrates that psychological effects of $\mathrm{CM}$ were highly statistically significant difference in urban areas $(100 \%)$ than in rural areas $(89.2 \%)$ that classified into increased responsibility after marriage $(\mathrm{p}=0.02)$,stress $\quad(\mathrm{p}=0.002)$, women not share in decision making with husband $(\mathrm{p}=0.01) \&$ misunderstanding with husband $(p=0.001)$,but there was no statistical significant difference in suffering from nervousness because of their marital life $(\mathrm{p}=0.06)$.

Table (5): shows that social effects of child marriage among studied women in both rural and urban areas were highly statistical significant in which conflicts between husbands \& wives that resulted from psychological reasons, marital reasons \& exposure to violence $(\mathrm{p}=0.000$ for each item) so that lead to divorce $(p=$ $0.000)$. 


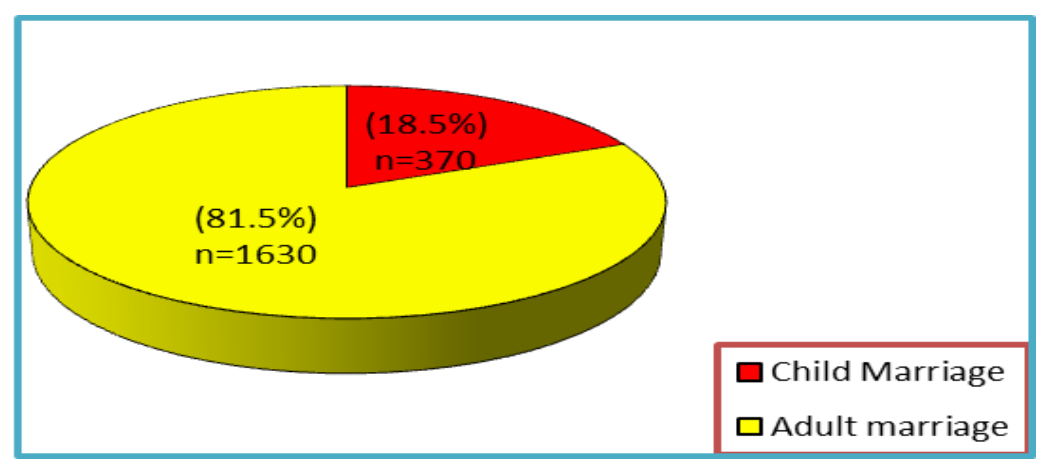

Fig. 1: shows that prevalence of child marriage among 2000 of married woman

Table (1): socio-demographic characteristics of rural \& urban studied women distributed by their residence $(\mathrm{N}=370)$

\begin{tabular}{|c|c|c|c|c|c|c|}
\hline \multirow{2}{*}{\multicolumn{2}{|c|}{$\begin{array}{l}\text { Socio demographic } \\
\text { characteristics }\end{array}$}} & \multicolumn{2}{|c|}{ Rural (185) } & \multicolumn{2}{|c|}{ Urban (185) } & \multirow{2}{*}{$\begin{array}{c}\mathrm{X} 2 \\
\text { P value }\end{array}$} \\
\hline & & No. & $\%$ & No. & $\%$ & \\
\hline $\begin{array}{l}\text { Current } \\
\text { Age / years }\end{array}$ & $\begin{array}{c}16- \\
27- \\
38-48\end{array}$ & $\begin{array}{c}102 \\
71 \\
12\end{array}$ & $\begin{array}{c}55.1 \\
38.4 \\
6.5\end{array}$ & $\begin{array}{l}83 \\
82 \\
20\end{array}$ & $\begin{array}{l}44.9 \\
44.3 \\
10.8\end{array}$ & $\begin{array}{c}\mathrm{X} 2=4.7 \\
\mathrm{P}=0.09 \mathrm{NS}\end{array}$ \\
\hline \multicolumn{2}{|c|}{ Mean \pm SD (Years) } & \multicolumn{2}{|c|}{$23.1 \pm 2.7$} & \multicolumn{2}{|c|}{$24.4 \pm 3.1$} & $\begin{array}{c}\mathrm{t}=1.12 \\
\mathrm{P}=0.43 \mathrm{NS}\end{array}$ \\
\hline $\begin{array}{l}\text { Age at } \\
\text { Marriage }\end{array}$ & $\begin{array}{l}14-17 \mathrm{Y} \\
(\mathrm{n}=370)\end{array}$ & 185 & 100 & 185 & 100 & NA \\
\hline \multicolumn{2}{|c|}{ Mean \pm SD (Years) } & \multicolumn{2}{|c|}{$15.0 \pm 2.1$} & \multicolumn{2}{|c|}{$16.4 \pm 1.7$} & $\mathrm{t}=0.52, \mathrm{P}=0.71 \mathrm{NS}$ \\
\hline $\begin{array}{l}\text { Educationa } \\
\text { I Level }\end{array}$ & $\begin{array}{l}\text { Illiterate. } \\
\text { R\& W } \\
\text { Moderate } \\
\text { education }\end{array}$ & $\begin{array}{l}53 \\
60 \\
72\end{array}$ & $\begin{array}{l}28.6 \\
32.5 \\
38.9\end{array}$ & $\begin{array}{c}28 \\
54 \\
103\end{array}$ & $\begin{array}{l}15.1 \\
29.2 \\
55.7\end{array}$ & $\begin{array}{c}\mathrm{X} 2=13.5 \\
\mathrm{P}=0.001 \mathrm{Sig}\end{array}$ \\
\hline Occupation & $\begin{array}{c}\text { Work } \\
\text { Not work }\end{array}$ & $\begin{array}{c}57 \\
128\end{array}$ & $\begin{array}{l}30.8 \\
69.2\end{array}$ & $\begin{array}{c}50 \\
135\end{array}$ & $\begin{array}{l}27 \\
73\end{array}$ & $\begin{array}{c}\mathrm{X} 2=0.64, \mathrm{P}=0.41 \\
\mathrm{NS}\end{array}$ \\
\hline $\begin{array}{l}\text { No. Of } \\
\text { children }\end{array}$ & $\begin{array}{l}1-3 \text { children } \\
4-6 \text { children }\end{array}$ & $\begin{array}{c}140 \\
45\end{array}$ & $\begin{array}{l}75.7 \\
24.3\end{array}$ & $\begin{array}{c}112 \\
73\end{array}$ & $\begin{array}{l}60.5 \\
39.5\end{array}$ & $\begin{array}{c}\mathrm{X} 2=7.6, \mathrm{P}=0.002 \\
\text { sig }\end{array}$ \\
\hline $\begin{array}{l}\text { Marital } \\
\text { status }\end{array}$ & $\begin{array}{c}\text { Married } \\
\text { Widowed } \\
\text { Divorced } \\
\text { Other }\end{array}$ & $\begin{array}{l}71 \\
19 \\
54 \\
41\end{array}$ & $\begin{array}{l}38.4 \\
10.3 \\
29.2 \\
22.2\end{array}$ & $\begin{array}{l}60 \\
14 \\
47 \\
64\end{array}$ & $\begin{array}{c}32.4 \\
7.6 \\
25.4 \\
34.6\end{array}$ & $\begin{array}{c}\mathrm{X} 2=7.2 \\
\mathrm{P}=0.07 \mathrm{NS}\end{array}$ \\
\hline \multicolumn{2}{|c|}{ Total } & 185 & 100 & 185 & 100 & \\
\hline
\end{tabular}

$\mathrm{NA}=$ Not applicable as all participants in either rural or urban areas were within one age group (14-17 years). 
Table (2): Distribution of the studied women according to their perception about child marriage $(\mathrm{N}=370)$

\begin{tabular}{|c|c|c|c|c|c|c|}
\hline \multirow{3}{*}{$\begin{array}{l}\text { Perception of child } \\
\text { marriage }\end{array}$} & \multicolumn{2}{|c|}{ Rural } & \multicolumn{2}{|c|}{ Urban } & \multicolumn{2}{|c|}{ X2 \& P value } \\
\hline & Yes & No & Yes & No & \multirow[t]{2}{*}{$\mathrm{X} 2$} & \multirow{2}{*}{$\begin{array}{c}\mathbf{P} \\
\text { value }\end{array}$} \\
\hline & No $\%$ & No $\%$ & No $\%$ & No $\%$ & & \\
\hline $\begin{array}{l}\text { Knowing the legal age of } \\
\text { marriage in Egypt }\end{array}$ & $40 \quad 21.6$ & $\begin{array}{l}145 \\
78.4\end{array}$ & $\begin{array}{ll}45 & 24.3\end{array}$ & 14075.7 & 0.38 & 0.53 \\
\hline $\begin{array}{l}\text { Child marriage help in the } \\
\text { growth of society }\end{array}$ & 6836.8 & $\begin{array}{l}117 \\
63.2\end{array}$ & $\begin{array}{ll}57 & 30.8\end{array}$ & 12869.2 & 1.5 & 0.22 \\
\hline $\begin{array}{l}\text { Child marriage happen } \\
\text { more among relatives }\end{array}$ & $\begin{array}{c}171 \\
92.4\end{array}$ & $14 \quad 7.6$ & 17594.6 & $10 \quad 5.4$ & 0.71 & 0.39 \\
\hline $\begin{array}{l}\text { Equality between girls } \\
\text { and boys in our society }\end{array}$ & 4423.8 & $\begin{array}{l}141 \\
76.2\end{array}$ & $\begin{array}{ll}29 & 15.7\end{array}$ & 15684.3 & 4.1 & 0.04 \\
\hline $\begin{array}{l}\text { The women perception } \\
\text { for reasons of child } \\
\text { marriage: }\end{array}$ & \multicolumn{2}{|c|}{$\begin{array}{r}\text { Yes } \\
\text { No. \% }\end{array}$} & \multicolumn{2}{|r|}{ No.\% } & $\mathbf{X}^{2}$ & $\begin{array}{c}\mathbf{P} \\
\text { value }\end{array}$ \\
\hline -Traditions & 19 & 10.3 & 7 & 3.8 & $\mathrm{LR}=36.2$ & $\begin{array}{c}0.000 \\
\text { HS }\end{array}$ \\
\hline -Education failure & 8 & 4.3 & 16 & 8.6 & & \\
\hline $\begin{array}{l}\text {-Insufficient income or } \\
\text { poverty }\end{array}$ & 33 & 17.8 & 58 & 31.4 & & \\
\hline $\begin{array}{l}\text {-The marriage of a cousin } \\
\text { or a relative }\end{array}$ & 53 & 28.6 & 23 & 12.5 & & \\
\hline - all the above & 66 & 35.8 & 75 & 40.5 & & \\
\hline - do not know & 6 & 3.2 & 6 & 3.2 & & \\
\hline $\begin{array}{l}\text { Persons encouraged } \\
\text { your child marriage } \\
\text { 1-Myself } \\
\text { 2- family members } \\
\text { 3- I do not know }\end{array}$ & $\begin{array}{l}22 \\
154 \\
9\end{array}$ & $\begin{array}{l}11.9 \\
83.2 \\
4.9\end{array}$ & $\begin{array}{l}21 \\
150 \\
14\end{array}$ & $\begin{array}{c}11.4 \\
81 \\
7.6\end{array}$ & $\mathrm{X} 2=1.2$ & $\begin{array}{l}0.55 \\
\mathrm{NS}\end{array}$ \\
\hline Total & 185 & 100 & 185 & 100 & & \\
\hline
\end{tabular}




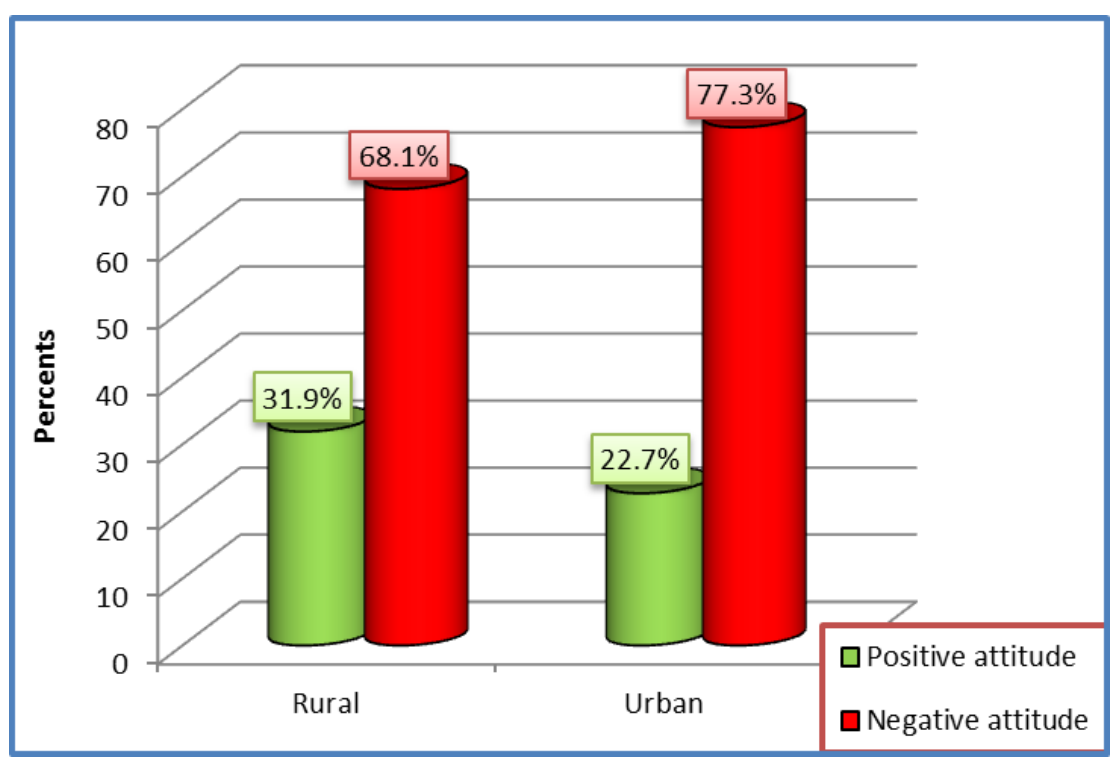

Fig.2: Groups of total attitude score in rural and urban areas toward child marriage

Table 3: Physical health consequences of child marriage among studied women in rural and urban areas.

\begin{tabular}{|c|c|c|c|c|c|c|}
\hline \multirow{2}{*}{$\begin{array}{l}\text { Physical health } \\
\text { consequences of } \\
\text { child marriage } \\
\text { among studied } \\
\text { women in rural and } \\
\text { urban areas }\end{array}$} & \multicolumn{2}{|c|}{ Rural (N=185) } & \multicolumn{2}{|c|}{ Urban(N=185) } & \multicolumn{2}{|c|}{ X2 \& P value } \\
\hline & \begin{tabular}{l}
\multicolumn{2}{c}{ Yes } \\
No $\%$
\end{tabular} & \begin{tabular}{c}
\multicolumn{2}{c}{ No } \\
No $\%$
\end{tabular} & \begin{tabular}{l}
\multicolumn{2}{c}{ Yes } \\
No $\%$
\end{tabular} & \begin{tabular}{l}
\multicolumn{2}{c}{ No } \\
No $\%$
\end{tabular} & $\mathbf{X 2}$ & $\begin{array}{c}\mathbf{P} \\
\text { value }\end{array}$ \\
\hline $\begin{array}{lr}\text { Child } & \text { marriage } \\
\text { affect } & \text { physical } \\
\text { health } & \\
\end{array}$ & 16790.3 & 18 & 16790.3 & $18 \quad 9.7$ & 1.0 & $\begin{array}{l}0.60 \\
\text { NS }\end{array}$ \\
\hline $\begin{array}{l}\text { Effect of child } \\
\text { marriage } \\
\text { health } \\
\text {-Repeated abortion } \\
\end{array}$ & 23.2 & 142 & 29.2 & 13170.8 & $X 2=1.7$ & $\begin{array}{c}\mathrm{P}= \\
0.19 \\
\mathrm{NS}\end{array}$ \\
\hline $\begin{array}{l}\text {-Occasional } \\
\text { bleeding }\end{array}$ & $25 \quad 13.5$ & $160 \quad 86.5$ & $\begin{array}{ll}56 & 30.3\end{array}$ & 12969.7 & $\mathrm{X} 2=15.2$ & $\begin{array}{c}0.000 \\
\text { HS }\end{array}$ \\
\hline $\begin{array}{l}\text {-Vaginal secretions } \\
\text { have a bad smell } \\
\text { /repeated vaginitis }\end{array}$ & $114 \quad 61.6$ & $71 \quad 38.4$ & 13371.9 & $52 \quad 28.1$ & $\mathrm{X} 2=3.8$ & $\begin{array}{c}0.03 \\
\text { Sig }\end{array}$ \\
\hline $\begin{array}{lr}\text {-Abnormal } & \text { vaginal } \\
\text { bleeding } & \text { with } \\
\text { intercourse } & \\
\end{array}$ & $\begin{array}{ll}36 & 19.5\end{array}$ & $149 \quad 80.5$ & $\begin{array}{ll}33 & 17.8\end{array}$ & 15282.2 & $\mathrm{X} 2=0.16$ & 0.68 \\
\hline incontinence ${ }^{\text {urinary }}$ & 74 & 11160 & 42.7 & 10657.3 & 0.27 & 0.59 \\
\hline -Different effect & 1.6 & $182 \quad 98.4$ & 4.8 & 17695.2 & 0.15 & 0.72 \\
\hline
\end{tabular}

Vol. 21 No. 2 May, 2021 
Tanta Scientific Nursing Journal( Print ISSN 2314 - 5595 ) ( Online ISSN 2735 - 5519 )

Table 4: Psychological effects of child marriage among studied women in rural and urban areas

\begin{tabular}{|c|c|c|c|c|c|c|c|c|}
\hline \multirow{3}{*}{$\begin{array}{l}\text { Psychological effects of } \\
\text { child marriage among } \\
\text { studied women in rural } \\
\text { and urban areas }\end{array}$} & \multicolumn{3}{|c|}{ Rural (N=185) } & \multicolumn{3}{|c|}{$\operatorname{Urban}(\mathrm{N}=185)$} & \multicolumn{2}{|c|}{ X2 \& P value } \\
\hline & Yes & \multicolumn{2}{|c|}{ No } & Yes & \multicolumn{2}{|c|}{ No } & \multirow[t]{2}{*}{$\mathbf{X} 2$} & \multirow[t]{2}{*}{ P value } \\
\hline & No $\%$ & No & $\%$ & No $\%$ & No & & & \\
\hline $\begin{array}{l}\text { Child marriage affect } \\
\text { women psychologically }\end{array}$ & $165 \quad 89.2$ & & 10.8 & 185100 & 0 & 0 & 21.1 & $0.000 \mathrm{HS}$ \\
\hline $\begin{array}{l}\text { If Yes: }(\mathbf{N}=\mathbf{1 6 5}) \\
\text {-Responsibilities increased } \\
\text { after marriage }\end{array}$ & $163 \quad 98.8$ & 2 & 1.2 & 100 & 0 & 0 & $\begin{array}{c}X 2=6 \\
1\end{array}$ & $\mathrm{P}=0.02 \mathrm{Sig}$. \\
\hline $\begin{array}{l}\text {-Suffering from } \\
\text { nervousness because of } \\
\text { their marital life }\end{array}$ & $165 \quad 100$ & 0 & 0 & $\begin{array}{ll}181 & 97.8\end{array}$ & & 2.2 & $\begin{array}{c}\mathrm{X} 2=3 \\
.4\end{array}$ & $0.06 \mathrm{NS}$ \\
\hline $\begin{array}{l}\text {-Suffer from stress due to } \\
\text { raising children }\end{array}$ & $160 \quad 97$ & 5 & 3 & $\begin{array}{ll}176 & 95.1\end{array}$ & 9 & 4.9 & $\begin{array}{c}\mathrm{X} 2=9 \\
.5\end{array}$ & $0.002 \mathrm{sig}$ \\
\hline $\begin{array}{l}\text {-Sharing the husband's } \\
\text { decision-making }\end{array}$ & 36.4 & 105 & 63.6 & 45.9 & 100 & 54.1 & $\begin{array}{c}\mathrm{X} 2=8 \\
.1\end{array}$ & $0.01 \mathrm{sig}$ \\
\hline $\begin{array}{l}\text {-Feeling misunderstanding } \\
\text { with husband }\end{array}$ & $108 \quad 65.5$ & 57 & 34.5 & 41.1 & 109 & 58.9 & 11.1 & $0.001 \mathrm{sig}$ \\
\hline
\end{tabular}

Table 5: Social effects of child marriage among studied women in rural and urban areas

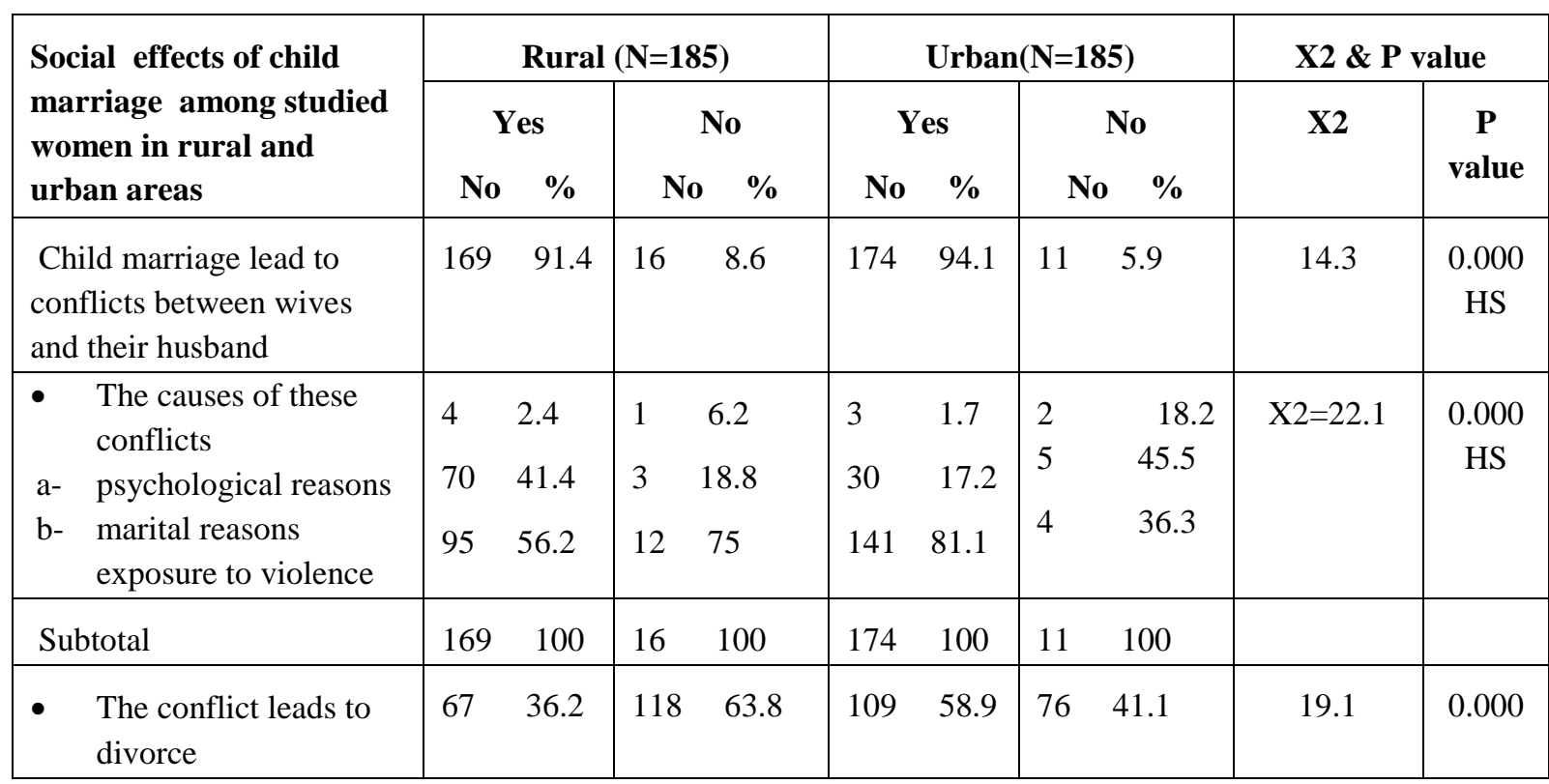




\section{Discussion}

Child marriage threatens children's wellbeing and constitutes multiple violations of their rights. In numerous contexts around the world, the practice has been shown to have profound physical, intellectual, psychological and emotional impacts, especially for girls (Adhikari, 2015) ${ }^{(6)}$.

Prevalence of child marriage among 2000 married women.

The current study aimed to assess the prevalence of child marriage in rural and urban communities. The prevalence of child marriage among studied women was $(18.5 \%)$ in rural \& urban areas at marriage with mean age at marriage (15.0 \pm 2.1$)$. This result is nearly consistent UNICEF, 2014 ${ }^{(10)}$ which reported that $17 \%$ of girls in Egypt are married before their 18th birthday. On the other side, this result isn't consistent with Yount, Crandall \& Cheong 2018 $^{(\mathbf{1 1})}$ which confirmed that $11 \%$ of adolescent girls with mean age at marriage $15 \pm 2$ years have previously been married.

\section{Socio-demographic characteristics of rural \& urban studied women}

Regarding to the mean age at marriage according to their residence, the studied females who live in urban areas, showed a slightly higher mean age of marriage (16.4 $\pm 1.7)$ years, compared to $(15.0 \pm 2.1)$ years among women live in rural area.
However, the difference was not statistically significant differences. This agreed with CAPMAS, (2017) ${ }^{(9)}$, which reported that the mean age $(15 \pm 2.0)$ are either currently married or were married before, with large differentials between the rural and urban residence ,the highest prevalence is found in rural regions with a relatively high proportion of households. On the other hand, this result was in contrary to Dube, Sharma, (2015) ${ }^{(12)}$, who found that the mean age was (14 \pm 1.7) in both regions because of neither recent progress in economic and women's development, nor existing policy or programmatic efforts to prevent child marriage and promote maternal and child health .

Concerning to level of education ,the current study revealed that there was higher significant difference in the level of education between rural and urban areas in which studied women in the illiterate level were in rural $32 \%$ and $29 \%$ in urban . The moderate education level was $38 \%, 55 \%$ in urban respectively. These results were in the same line to a study done by Pandya and Bhanderi, (2015) ${ }^{(13)}$, who found that, the majority of the participants were uneducated 33\%, about $32.7 \%$ respondentshad up to primary education and $36.6 \%$ had middle school education as a cause $\&$. 
Regarding to occupation, the current study revealed that majority of studied women not working with no statistical difference between rural and urban areas as a result of big responsibilities and burden of home needs. This study with the same line to Bani Fatemeh, Abbaszadeh, Alizadeh Aghdam, Mohammadpour, $2018{ }^{(14)}$; who reported that 25 percent women are expected to assume domestic responsibilities such as care work, including child and elder care, as well as domestic chores as cooking and laundry.

\section{Perception of child marriage}

Concerning to perception for child marriage in rural and urban communities which include: knowledge of the legal age of marriage help in growth of the society, happen more among relatives. Current study showed that more than three quarters of the studied women in both urban \& rural areas demonstrated that, they do not know the meaning \& the legal age of marriage in Egypt and occurs more between relatives. These findings in the line with Dube \& Sharma, (2015) ${ }^{\text {(12) }}$ who stressed that, most respondents were uneducated, poor and were working as housemaids. The majority participants were unaware of age $\&$ consequence of child marriage

negative health outcomes of child marriages. They appeared satisfied by the decision of their parents of marrying them before 18 years, Strong influence of culture and community perceptions, varying interpretation of religion, and protecting family honor are some of the perception.

Concerning to reasons of child marriage, the current study revealed that tradition, education failure, insufficient income or poverty in addition to the marriage of the cousin or relatives in both rural $\&$ urban areas. These results were agreed with Stark, (2018) ${ }^{(\mathbf{1 5})}$ who stated that, poverty could constrain women's choices and prompt them to marry earlier than otherwise preferable.

Regarding to education as a reason, the current study revealed that education failure, far distance and poor economic status of parents lead to child marriage, this result was with the same line of International Center for Research in Women (ICREW, 2017) (16) in a conference for solutions to end child marriage which reported that, schools are of poor quality, sometimes far away, or costly for families, this leads to encourage parents to marry off their girls \&reprioritizing girls education.

\section{Attitudes toward child marriage}

Attitudes of toward child marriage in the current study showed that, the majority of studied women regarding their attitude and trends toward child marriage stated that, child marriage increase responsibility 
of girls after marriage prevents spinsterhood\& maintains virginity.

In addition to, this practice wastes woman rights \& leads to negative effects and not satisfied with it, so they encourage its prevention. These results accepted with (Nasrullah, 2014) ${ }^{(17)}$ who found that women who were aware of the negative health impacts of child marriage \& were against the marriage of their daughters before the age of 18 years. These women wanted their daughters to get education and better social status in the society and protect daughter from negative health impacts against child marriage.

\section{Health consequences of child marriage}

Concerning to physical consequences of child marriage on women lived in rural and urban communities, Current study demonstrated that there was a highly statistical significant difference between rural and urban women regarding occasional bleeding and repeated vaginitis which they were the most common effects while, there was no statistical significant difference in abnormal vaginal bleeding with intercourse and urinary incontinence related to muscles weakness of uterine \& bladder in both areas groups. These results was in the same line with the results reported by Ministry of Health and Population, (2014) $)^{(\mathbf{1 8})}$, who stated that Egypt Demographic and Health Survey for married adolescent girls in Egypt ; suggested that girls who marry before the age of 18 are more at risk of contracting diseases as they do not receive a premarital examination \& The exceptionally low knowledge of diseases among youth makes young girls vulnerable to infection as they engage in risky practices.

Regarding to psychological consequences of child marriage, child marriage, current study reflected highly statistical significant difference in urban areas $(100 \%)$ than in rural areas $(89.2 \%)$ that classified into increased responsibility after marriage, stress, women not share in decision making with husband \& misunderstanding with husband which resulted in statistically significant difference in both areas regarding to psychological problems resulted from child marriage as depression, suffering from nervousness because of their marital life. These results were consistent with Klugman, et al., (2014) (4). Who demonstrated that child girls are often vulnerable as they are young, often poorly educated, and possibly limiting their decision-making ability, including in regard to disadvantaged socio-economic backgrounds. When they marry early, they may fall even more under the control of their husband they had married later. This may limit their aspirations, as well as agency. 
Furthermore, limiting girls' decisionmaking ability in regard to access to healthcare during pregnancy and delivery as another psychological effect. This was agreed with Parson, (2015) ${ }^{(\mathbf{1 9})}$ \& Kidman, (2016) ${ }^{(20)}$ who stressed that child marriage reduces girls and women's decisionmaking ability in the household, less of freedom and a feeling of isolation for the girl-child as well as an unhappy marriage . Current study demonstrated that social problems were considered consequence of child marriage and there were highly statistical significant difference between rural and urban women which mean that rural women unable to raise their children more than urban women, divorce \& separation common related to marital problems, respectively. These results in the same line with Raj, (2016) ${ }^{(2)}$, which supported that literate women are more aware of health and reproductive issues and the importance of children's education, while girls who were not adequately educated and prepared for the roles expected of them in the family. This therefore becomes a burden and has serious impact on their psychological welfare, their perception of themselves and also their relationship.

In addition to social conflicts result as divorce $\&$ separation as a social effect, the current study which approved that divorce is observed generally 11.2 percent as in rural more than urban related to the partner conflict. This result agreed with International Center for Research in Women (ICRW), $2017^{(16)}$; reported that there were evidences of the links of child marriage with divorce, abandonment, separation, widowhood and denial of property rights.

\section{Conclusion}

Child marriage is a complex issue, rooted deeply in gender inequality, tradition, failure of education and poverty. Despite national law, the practice is widely prevalent in rural and urban areas clearly in the study which indicated that attitudes, motives, health consequences of women adequate to sufficiently curb the social evil of child marriage. The outcome of the study necessitates stricter awareness, better educational opportunities for girls. Particularly, after marriage, awareness for negative consequences and easy access to quality health services.

\section{Recommendations}

-Address the factors that drive child marriage, including poverty, insecurity, and the lack of opportunities for girls, traditional roles of wives and mothers, and gender inequality.

-Raising the level of awareness about negative outcomes of child marriage by intensifying the Health education activities. 
-Rehabilitation programs for social, psychological problems of child marriage. -Provision of economic opportunities for women \& enhancing culture and community perception of child marriage can help to eliminate the child marriage practice.

-Ensure that family planning programs \&Provide safe spaces for adolescent married girls to interact, exchange information and learn about their rights as education, decision making.

-Prioritization of girls' education \& decreasing the obstacles that faces in order to end child marriage.

\section{References}

1. UNICEF, State of the World's Children, 2017.

2. Raj A, Saggurti N, Lawrence D, Balaiah D, Silverman JG. Association between adolescent marriage and marital violence among young adult women in India. International Journal of Gynecology \& Obstetrics. 2016; 110(1):35-9.

\section{UNFPA (United Nations Population}

Fund). Marrying too young; End child marriage [Online] New York, USA.2014. http://www.unfpa.org/ sites/default/files/pub

/MarryingTooYoung.pdf [Accessed 14-11-10].

4. Klugman J, Hanmer L, Twigg S, Hasan T, McCleary-Sills J,
Santamaria J. Voice and agency: Empowering women and girls for shared prosperity. The World Bank; 2014 Sep 29.

5. World Health Organization. Global accelerated action for the health of adolescents (AA-HA!):guidance to support country implementation.May 2017.

6. Adhikari R, Soonthorndhada K, Prasartkul P. Correlates of unintended pregnancy among currently pregnant married women in Nepal. BMC International Health and Human Rights. 2015; 9(1):17.

7. Santhya KG, Ram U, Acharya R, Jejeebhoy SJ, Ram F, Singh A. Associations between early marriage and young women's marital and reproductive health outcomes: evidence from India. International Perspectives on Sexual and Reproductive Health. 2017; 36(3):132-39.

8. Deepa Naryan, ed., Measuring Empowerment: Cross-Disciplinary Perspectives Washington, D.C.: The World Bank, 2015,72.

9. CAPMAS. Egypt Census of Population, Housing and Establishments, Egypt; 2017.

10. UNICEF. The national strategy to end child marriage and teenage pregnancy $2014 / 2015-2019 / 2020$. A society free 
from child marriage and teenage pregnancy. 2015.

11. Yount KM, Crandall A, Cheong YF. Women's age at first marriage and long-term economic empowerment in Egypt. World development. 2018; 102 (1):124-34.

12. Dube. S., and Sharma. Knowledge, Attitude and Practice Regarding Reproductive Health among Urban and Rural Girls: A Comparative Study, Ethno Med. 2015; 6(2): 85-94.

13. Pandya YP, Bhanderi DJ. An epidemiological study of child marriages in a rural community of Gujarat. Indian journal of community medicine: official publication of Indian Association of Preventive \& Social Medicine. 2015 Oct; 40(4):246.

14. Bani Fatemeh $H$, Abbaszadeh $M$, Alizadeh Aghdam MB, Mohammad pour N. Stress and violence against women: a qualitative research. Women in Development \& Politics. 2018 Dec 22; 16(4):581-602.

15. Stark L. Poverty, consent, and choice in early marriage: ethnographic perspectives from urban Tanzania. MarriageFam Rev. 2018; 4929:1-17.

\section{International Center for Research} on Women (ICRW). Too Young to Wed, Child Marriage in the own Words Washington, DC; 2017.
17. Nasrullah M, Zakar R, Zakar MZ, Kramer A. Girl-child marriage and its association with morbidity and mortality of children under 5 years of age in a nationally-representative sample of Pakistan. J Pediatr.2014; 164:639-646.

doi:

10.1016/j.jpeds.2013.11.017.

18. Ministry of Health and Population. Egypt Demographic and Health Survey, Egypt; 2014.

19. Parsons, J., J. Edmeades, A. Kes, S. Petroni, M. Sexton, and Wodon. Q.. Economic Impacts of Child Marriage: A Review of the Literature, Review of Faith and International Affairs, 2015; 13(3): 12-22.

20. Kidman R. Child marriage and intimate partner violence: a comparative study of 34 countries.International journal of epidemiology. 2017;46(2):662-75. 